tekst, der provokerer én til at tage stilling. Også oversætterne har gjort et godt arbejde med mundrette ordvalg og prægnante formuleringer $i$ et udvalg, der fungerer fint sammen med et meget grundigt efterskrift forfattet af lektor Mikkel Thorup. Efterskriftet fokuserer på Rousseaus originalitet og politiske temaer fra forfatterskabet, der stadig har stor aktualitet. Kombineret med et udvidet noteapparat er det derfor en udgivelse, der for alvor gør det muligt at arbejde videre med Rousseaus tekster - uanset om læserens interesse så mest er filosofisk eller historisk.

MATHIAS HEIN JESSEN

\section{Oplysning om Oplysningen}

Jonathan I. Israel: A Revolution of the Mind - Radical Enlightenment and the Intellectual Origins of Modern Democracy, Princeton University Press, 2009, 296 sider, $\$ 26.95$.

A Revolution of the Mind er tredje udgivelse i idéhistorikeren Jonathan I. Israels storstilede forsøg på at genbeskrive oplysningstiden. Hans enorme arbejde omfatter, udover A Revolution of the Mind, Radical Enlightenment (2001), Enlightenment Contested (2006) samt et kommende bind, der skal føre fortællingen frem til og med den franske revolution. A Revolution of the Mind er med sine knap 300 sider en del kortere end de to foregående bind, der hver fylder omkring de 1000 sider, og fungerer både som en lettilgængelig introduktion til Israels værk og tanker samt som en bro mellem 1752, hvor Enlightenment Contested slutter, og frem til årtierne umiddelbart før den franske revolution.

Israels provokerende tese er, at de tidligere udlægninger af oplysningstiden har været forkerte og dermed forhindret os i virkelig at forstå oplysningen, årsagerne til den franske revolution og ikke mindst filosofiens rolle i den. For Israel skal oplysningstiden nemlig ikke forstås som én samlet bevægelse mod fornuft, frihed, lighed og tolerance og heller ikke som forskellige nationale oplysninger med særegne karakteristika, men derimod som en kamp mellem to modstridende strømninger: den radikale og den moderate oplysning.

Noget af det mest interessante i Israels værk er dermed, hvordan han placerer oplysningstidens traditionelle helte; dem, der har en fast plads i den filosofihistoriske kanon, og dem, der traditionelt udråbes som frihedens og fornuftens forkæmpere, som moderate tænkere. Folk som Locke, Hume, Frederik den Store, Voltaire (og 
mange, mange flere), der advokerede for øget frihed, større brug af fornuften og en tro på fremskridtet, var dog overbeviste om, at dette fremskridt måtte ske inden for den bestående orden. De forsvarede traditionens, kirkens, aristokratiets og monarkiets autoritet som den bedste måde at organisere samfundet på. Ifølge de moderate tænkere var det nemlig langt fra alle, der var klar til oplysning eller til at bruge deres egen fornuft. Oplysningen skulle dermed reserveres de få.

I modsætning hertil opstiller Israel den radikale oplysning, der kæmpede for oplysning til alle og for fornuftens universelle herredømme i alle livets aspekter, såvel politisk og moralsk som kulturelt. De radikale tænkere gik ind for universel lighed (også seksuelt og racemæssigt), fuld og universel ytrings-, tros- og pressefrihed såvel som repræsentativt demokrati. Grunden til al verdens uretfærdighed og elendighed lokaliserede de hos den bestående ordens sociale stratifikation og hierarkisering. De egalitære værdier kunne dermed ikke indføres uden en gennemgribende forandring af de bestående forhold. Sådanne tanker var selvsagt en torn i øjet på magthaverne i l'ancien regime, og de radikale tænkere, som bl.a. omfattede Pierre Bayle, Denis Diderot, Baron d'Holbach og mange flere, måtte derfor udgive deres skrifter anonymt.

Ikke desto mindre viser Israel, at de radikale tanker havde en enorm indflydelse og klangbund i samtiden, og han mener samtidig, at det var disse tanker, der sammenfattede de sociale lidelser i tiden. Filosofien var dermed en afgørende faktor ikke bare i den franske, men også i den amerikanske og den hollandske revolution.

Israel daterer ligeledes oplysningstidens begyndelse før den gængse opfattelse, i og med at han gør Baruch de Spinoza til den radikale oplysnings intellektuelle ophav. Og her begynder Israel at blive særdeles problematisk. Han mener nemlig, at de radikale tænkere alle var inspirerede af Spinozas monistiske én-substans lære, der, fordi den er filosofisk sand og konsistent, også blev den historiske sejrherre, idet den radikale tradition leverede det blueprint for democracy (s. 66), der senere blev indført $i$ de vestlige demokratier efter 1945. Sådan et postulat er idéhistorisk noget problematisk, men ikke desto mindre er Israels værk imponerende læsning og et enormt arbejde, hvor man fristes til at tro, at han har været nede i samtlige værker, pamfletter og brevvekslinger fra tiden.

Dikotomien mellem den radikale og moderate oplysning bliver dog til tider for rigid, når alle tænkere skal puttes ned i de forhånds- 
bestemte kasser (hvorfor Israel også bliver nødt til at lave en særlig kategori til Rousseau, og til dels også til Kant). Værket giver imidlertid et interessant nyt blik på en afgørende epoke i den europæiske (og verdens) historie og lokaliserer ikke mindst en betydningsfuld og indflydelsesrig radikal tradition, der ikke før er behandlet så grundigt. Det bliver dermed et must for alle, der beskæftiger sig med oplysningstiden. Men pas på: Den lettilgængelige og korte stil gør, at Israels pointer ofte fremstår uforklarede og postulatoriske, og man drages derfor mod de større og mere udførlige værker - hvilket selvfølgelig er et godt salgstrick.

NANNA KATRINE LÜDERS KAALUND

\section{Darwin på dansk}

Charles Darwin: Arternes Oprindelse ved Naturlig Selektion eller Bevarelse af de bedst tilpassede racer $i$ kampen for tilvarelsen, oversat af Jorn Madsen, forord af Peter C. Kjargaard, Statens Naturbistoriske Museeum, 2009, 388 sider, 249,- kr.

Den 24. november 1859 blev en af alle tiders mest omtalte og diskuterede bøger publiceret. Forfatteren var Charles Darwin, og bogen hed On the Origin of Species by Means of
Natural Selection, or the Preservation of Favoured Races in the Struggle for Life. Hovedargumentet i Origin var, at arterne ikke var blevet skabt hver for sig, og at mekanismen, hvorved arterne over tid havde forandret sig, var naturlig selektion. I indledningen til Origin skriver Darwin således, at "Jeg er overbevist om, at arter ikke er uforanderlige, men at de, der hører til samme slægt, nedstammer fra andre, oftest uddøde arter, på samme måde som en art kan give ophav til en række varieteter."

Origin blev udsolgt på udgivelsesdagen og skabte øjeblikkelig stor debat $i$ alle samfundslag, en debat, der stadig er aktuel i det 21. århundrede. Darwin var dog ikke den første, der havde fremlagt en teori om livets udvikling. I 1844 blev værket Vestiges of the Natural History of Creation udgivet af en anonym forfatter. Vestiges vakte en enorm furore og modtog megen kritik for sit indhold, der i høj grad manglede videnskabelig underbygning. Den negative modtagelse af Vestiges var uden tvivl medårsag til, at Darwin ventede så længe med at publicere sine idéer, som han gjorde. Omkring samtidig med udgivelsen af $V$ estiges havde Darwin udfærdiget et længere manuskript, der indeholdt en skitse af hans teori. Dette manuskript ville han ikke publicere endnu, men fik det arrangeret således, at det ville blive offentlig- 